\title{
ANALISIS MUATAN NILAI-NILAI KARAKTER PADA BUKU TEKS KURIKULUM 2013 PEGANGAN GURU DAN PEGANGAN SISWA
}

\author{
Sasi M ardikarini dan Suwarjo \\ Program Pascasarjana Universitas Negeri Yogyakarta \\ email: sasimardikarini@ymail.com
}

\begin{abstract}
A bstrak: Penelitian ini bertujuan untuk mendeskripsikan nilai-nilai karakter pada buku pegangan guru, nilai-nilai karakter pada buku pegangan siswa, dan kesesuaian nilai-nilai karakter pada buku teks Kurikulum 2013 pegangan guru dan buku pegangan siswa. Penelitian ini merupakan penelitian analisis konten dengan pendekatan kualitatif melalui empat tahap, yaitu pengadaan data, reduksi data, inferensi, dan analisis data. Sumber data penelitian adalah buku teks Kurikulum 2013 pegangan guru dan pegangan siswa kelas I semester 1 yang terdiri atas empat tema, yaitu tema "Diriku", "Kegemaranku", "Kegiatanku", dan "Keluargaku". Unit analisis adalah nilai-nilai karakter yang terkandung dalam buku teks. Hasil penelitian yaitu: (1) buku pegangan guru mengembangkan semua nilai karakter yang dianalisis; (2) buku pegangan siswa pada tema diriku dan keluargaku tidak mengembangkan nilai kejujuran, pada tema "Kegemaranku" dan "Kegiatanku" tidak mengembangkan nilai tanggung jawab; (3) nilai karakter pada buku pegangan guru dan pegangan siswa tema "Diriku" dan "Kegemaranku" telah sesuai, sedangkan pada tema "Kegiatanku" dan "Keluargaku" masih terdapat nilai karakter yang belum sesuai.
\end{abstract}

Kata kunci: nilai-nilai karakter, buku teks kurikulum 2013, sekolah dasar

\section{AN ANALYSIS OF CHARACTER VALUES CONTENT IN THE 2013 CURRICULUM COURSE-BOOK OF TEACHER HANDBOOK AND STUDENTS HANDBOOK}

\begin{abstract}
A bstract: This research aims to describe (1) the caracter value in teacher handbook content; (2) the character value in student handbook content; (3) the suitability of the character value in course-bookcurriculum 2013 teacher handbook and student handbook. This research was a content analysis using the qualitative approach with four procedure (1) data collecting (unitizing, sampling, recording); (2) reducing; (3) inferring; 4) data analysis. The subject used in this study was course-book of curriculum 2013 teacher handbook and student handbook of the first grade of elementary school in the first semester, namely myself theme, my hobby theme, my activities theme, and my family theme. The unit analysis of this research is the character contained in the course-book. The result of this study are (1) teacher handbook within each theme has been developing all the character value; (2) handbook student on the theme of my self and my familiy did not develop the values of honesty, while the theme of my passion and my activities did not develop the values of responsibility; (3) character value of handbook teacher and handbook student on the my self and my hobby theme has been appropriate, while the my activities and my family theme still there character of value was not corresponding.
\end{abstract}

Keyw ord: character value, textbook of curriculum 2013, elementary school

\section{PENDAHULUAN}

Perkembangan zaman yang berupa kemajuan ilmu pengetahuan dan teknologi menjadikan informasi tersebar cepat. Me dia penyebaran informasi di antaranya internet dan televisi dapat diakses oleh semua orang, termasuk anak-anak. Mirisnya, informasi yang berupa perkelahian, bullying, tawuran antarpeserta didik, pacaran bebas, dan pemerkosaan sering terdengar belakangan ini. Kejadian tersebut sering terjadi bukan hanya pada kalangan dewasa namun lebih mirisnya terjadi di kalangan anak usia sekolah. Alasan terbesar adanya kejadian ini adalah karena kurangnya pengembangan nilai-nilai karakter dalam diri peserta didik. 
Beberapa kejadian akibat kurangnya pengembangan nilai karakter terjadi pada anakusia sekolah dasar. Kasus pengeroyokan yang dilakukan oleh teman sekelas dan direkam oleh teman lainnya di sebuah SD, kasus pacaran anak SD yang berujung pada korban hamil, serta kasus pencurian yang dilakukan oleh siswa SD terhadap kepala sekolahnya menunjukkan kurangnya nilai karakter yang dikembangkan pada diri peserta didik. Kejadian tersebut membuktikan bahwa penurunan moral sudah sangat mengenaskan. Kasus seperti ini harus segera diatasi oleh berbagai pihak terkait agar generasi bangsa ke depan dapat berkembang dengan lebih baik. Salah satu bentuk pencegahanya adalah melalui pendidikan.

Pendidikan akan semakin baik me Ialui proses evaluasi dalam jangka waktu tertentu. Hasil evaluasi menghasilkan penggunaan Kurikulum 2013 pada proses pembelajaran di sekolah. Kurikulum 2013 digunakan sejak tahun 2013 untuk kelas I dan IV SD, dan dilanjutkan untuk kelas lainnya pada semester berikutnya. Untuk saat ini (2015), Kurikulum 2013 hanya dilaksanakan pada sekolah yang telah melaksanakan Kurikulum 2013 selama 3 semester, sedangkan sekolah lainnya kembali ke Kurikulum Tingkat Satuan Pendidikan (KTSP) sehingga untuk saat ini pendidikan Indonesia menggunakan dua kurikulum yaitu Kurikulum 2013 dan Kurikulum Tingkat Satuan Pendidikan (Peraturan Menteri Pendidikan dan Kebudayaan No. 160 Tahun 2014).

Kurikulum 2013 memuat empat kompetensi di dalamnya, yaitu kompetensi religius, sosial, pengetahuan, dan keterampilan (Peraturan Menteri Pendidikan dan Kebudayaan Nomor 57 Tahun 2014). Berdasarkan keempat kompetensi tersebut, kompetensi religius dan kompetensi sosial mewakili pengembangan karakter pada diri siswa selama proses pembelajaran. Karakter yang dikembangkan berdasarkan kedua kompetensi tersebut yaitu religius, jujur, disiplin, tanggung jawab, santun, peduli, dan percaya diri. Karakter tersebut dapat berkembang secara maksimal jika dalam pembelajaran juga dikembangkan nilai-nilai karakter tersebut. Nilai karakter yang dimaksud adalah nilai religiusitas, kejujuran, kedisiplinan, tanggung jawab, kesantunan, kepedulian, dan kepercayaan diri. Nilai karakter merupakan salah satu upaya dalam membentuk manusia secara utuh (holistik) yang berkarakter, yaitu mengembangkan aspek fisik, emosi, sosial, kreativitas dan intelektual secara optimal (Muryaningsih \& Mustadi, 2015:193).

Karaktermerupakankepribadian atau akhlak seseorang yang digunakan sebagai landasan dalam menentukan cara pandang, berpikir, bersikap, dan bertindak. Nucci \& Narvaes (2008:415) menegaskan, "Character is the set psychological characteristic that motivate and enable an individual to funcion as a competent moral agent". Karakter yang terdapat dalam diri seseorang dapat membentuk moral seseorang. Karakter baik akan membentuk moral yang baik, begitu juga sebaliknya. Oleh sebab itu, pengembangan nilai-nilai karakter perlu mendapat perhatian yang serius oleh guru agar karakter dalam diri siswa dapat berkembang dengan baik.

Pengembangan karakter pada diri seseorang akan membedakan seseorang de ngan orang lain. Bohlin (2005:159) mengungkapkan, "C haracter is that distinctive mark of our person; the combination of these distinguishing that make us who we are. Character is deeper than appearance and reputation and constitues more than our personality or temperament." Pendapat tersebut menguatkan bukti bahwa karakter merupakan ciri khas dari seseorang yang menjelaskan siapa diri 
kita, dan membedakan diri kita dari orang lain.

Pengembangan atau pendidikan karakter kepada seseorang akan lebih tertanam jika dilakukan sejak dini. Salah satu tempat pengembangan dan pendidikan karakter yang baik adalah melalui sekolah. Pendidikan tingkat dasar merupakan akar pendidikan selanjutnya sehingga keberhasilan pada pendidikan dasar akan sangat menentukan proses belajarnya di jenjang yang lebih tinggi (Sasmito \& M ustadi, 2015: 70). Hal ini menyimpulkan bahwa pendidikan pada jenjang sekolah dasar harus dilaksanakan dengan baik.

Pendidikan karakter atau pengembangan nilai-nilai karakter di sekolah dapat dikembangkan melalui berbagai kegiatan, antara lain kegiatan dalam pembelajaran dan kegiatan di luar pembelajaran. Salah satu cara pengembangan nilai-nilai karakter dalam proses pembelajaran, yaitu meIalui pengintegrasian nilai karakter padakegiatan pembelajaran. Pengintegrasian pendidikan nilai (karakter) pada setiap pelajaran menjadi sangat penting demi kesiapan siswa dalam menghadapi setiap permasalahan dalam kehidupannya (Qodriyah \& Wangid, 2015:179). Pendapat ini membuktikan bahwa dalam proses pembelajaran tidak hanya ditanamkan nilai-nilai kognitif saja pada pribadi peserta didik tetapi juga pengembangkan nilai-nilai karakter peserta didik.

Pengembangan nilai-nilai karakter pada peserta didik dalam pembelajaran dapat dilakukan dengan berbagai hal. Salah satunya melalui buku teks sebagai sumber belajar peserta didik. Buku teks dapat digunakan sebagai media untuk mengembangkan nilai-nilai karakter dalam pembelajaran. El-Saleh (2011:2) menegaskan, "Textbooks are primary physical resource for students performance in the classrooms. Teacher's editions of textbooks are an asset that helps them create lesson plans by providing explanations, classroom discussion techniques, and examples of students errors or misconceptions." Penjelasan tersebut menguatkan bukti bahwa buku teks dalam dijadikan sumber belajar di dalam kelas, karena buku teks dapat lebih sering berinterksi langsung dengan peserta didik dibandingkan dengan guru kelasnya.

Buku teks juga dapat dijadikan "alat" untuk mencapai tujuan yang diharapkan. Costanzo (2009:4) menyatakan, "Textbooks purpose is to serve as vehicles for the transmission of knowledge, and it is important not to overlook the social dimension within that knowledge is made legitimate." Buku teks diberikan langsung kepada siswa dengan tujuan siswa dapat menemukan sendiri pengetahuan yang diberikan. Guru dalam hal ini hanya sebagai fasilitator pembelajaran.

Perkembangan zaman mendorong perkembangan bentuk buku teks atau sumber belajar peserta didik. Buku teks untuk siswa sekolah dasar sekarang ini menggunakan buku teks Kurikulum 2013 dan buku teks Kurikulum Tingkat satuan Pendidikan. Khusus untuk buku teks Kurikulum 2013 di dalamnya termuat kompetensi religius dan kompetensi sosial yang memuat nilai-nilai karakter yang harus ditanamkan pada peserta didik. Buku teks Kurikulum 2013 terdiri atas dua macam, yaitu buku pegangan guru dan buku pegangan siswa. Buku dibuat berdasarkan tema tertentu dengan bagian buku yang berbeda-beda. M uatan nilai-nilai karakter dalam buku teks Kurikulum 2013 dirancang berdasarkan karakteristik dan strategi pendidikan karakter untuk masing-masing jenjang.

Bagian-bagian buku pegangan guru antara lain kata pengantar, tentang buku guru, cara penggunaan buku guru, panduan penilaian, $S K L \& K I, K D$, ruang lingkup 
dan halaman pembelajaran (Kemdikbud, 2014:45-46). Halaman pembelajaran terdiri dari bagian pemetaan indikator, tujuan pembelajaran, media/ alat/ sumber belajar, kegiatan pembelajaran, pengayaan dan remidian, serta penilaian. Bagian dari buku siswa antara lain aktivitas kegiatan siswa, belajar dengan orang tua di rumah, dan lembar kerja atau evaluasi siswa (Kemdikbud, 2014:42). Masing-masing bagian dalam buku siswa diharapkan dapat memuat nilai karakter yang diharapkan akan dikembangkan pada diri peserta didik.

Berdasarkan penjelasan di atas penelitian ini bertujuan untuk mengetahui nilainilai karakter yang termuat dalam buku teks Kurikulum 2013 pegangan guru, nilai-nilai karakter yang termuat dalam buku teks Kurikulum 2013 pegangan siswa, dan kesesuaian nilai karakter pada buku pegangan guru dan buku pegangan siswa kelasI semester 1. Masing-masing tujuan pembelajaran tersebut akan menjelaskan nilai karakter pada masing-masing tema.

\section{METODE}

Penelitian ini merupakan penelitian analisis konten dengan pendekatan kualitatif. Penelitian ini bertujuan unruk mendeskripsikan dan membuat kesimpulan yang valid dan dapat diteliti ulang. Bagian yang dianalisis adalah nilai karakter yang terdapat pada buku teks Kurikulum 2013 pegangan guru kelas I semester 1 , nilai karakter yang terdapat pada buku teks Kurikulum 2013 pegangan siswa kelas I semester 1, dan kesesuaian nilai karakter pada buku teks Kurikulum 2013 pegangan guru dan pegangan siswa.

Penelitian dilakukan dengan menganalisis dokumen berupa buku teks Kurikulum2013 kelas I semester 1 terbitan Kementerian Pendidikan danKebudayaan $\mathrm{Ta}$ hun 2014. Buku teks Kurikulum 2013 telah digunakan di sekolah pilot project di Indonesia. Penelitian dilaksanakan pada bulan Januari hingga Maret.

Sumber data dalam penelitian ini adalah buku teks Kurikulum 2013 pegangan guru dan pegangan siswa kelas I semester 1 sekolah dasar yang diterbitkan oleh Kemdikbud. Buku teks Kurikulum 2013 terdiri atas empat tema, yaitu tema "Diriku", "Kegemaranku", "Kegiatanku", dan "Keluargaku". Unit analisis dalam penelitian ini adalah nilai-nilai karakter yang terkandung pada seluruh bagian buku.

Pengumpulan data dalam penilitian ini dilakukan dengan analisis isi dan pencatatan secara cermat terhadap buku teks pelajaran Kurikulum 2013 pegangan guru dan pegangan siswa kelas I semester $1 \mathrm{Se}$ kolah Dasar. Instrumen utama dalam penelitian ini adalah human instrument, yaitu peneliti sendiri, dengan cara memasukkan dalam rubrik analisis yang disusun berdasarkan landasan teori terkait nilai-nilai karakter.

Keabsahan data didasarkan pada validitas. Validitas yang digunakan dalam penelitian ini adalah validitas semantik. Validitas semantik digunakan untuk mengetahui kesesuaian analisis kategori teks dengan konteks yang dipilih. Reliabilitas instrumen yang digunakan dalam penelitian ini adalah reliabilitas stabilitas dan reliabilitas re plikabilitas. Reliabilitas stabilitas dilakukan dengan pembacaan berulang untuk mendapatkan pemahaman, sedangkan relibilitas replikabilitas dilakukan dengan cara diskusi dan konfirmasi dengan teman sejawat.

Prosesdur analisi konten yang digunakan terdiri atas empat langkah, yaitu pengadaan data, reduksi data, inferensi, dan analisis data (Krippendorf, 2013:84). Tahap pengadaan data terdiri dari 3 bagian yaitu penentuan unit analisis, penentuan sampel, 
dan perekaman, atau pencatatan. Reduksi datadilakukan dengan menghilangkan halhal yang tidak sesuai dengan nilai-nilai karakter yang dianalisis. Inferensi dilakukan dengan menggunakan kriteria penentuan nilai karakter yang terdapat dalam teks. Tahap analisis data merupakan tahap pendeskripsian data analisis yang diperoleh. Analisisi data menggunakan teknik analisis kualitatif.

\section{HASIL DAN PEMBAHASAN Hasil Penelitian}

Hasil penelitian dikelompokkan menjadi 3 bagian, yaitu nilai-nilai karakter pada buku pegangan guru, nilai-nilai karakter pada buku pegangan siswa, dan kesesuaian nilai-nilai karakter pada buku pegangan guru dan pegangan siswa kelas I semester 1. Masing-masing bagian tersebut menjelaskan empat tema yang terdapat dalam buku teks Kurikulum 2013 kelas I semester 1, yaitu tema "Diriku", "Kegemaranku", "Kegiatanku", dan "Keluargaku". Setiap bagian yang dianalisis memiliki hasil yang berbeda-bedasesuai dengan fokus pengembangan nilai-nilai karakter yang ada.

\section{Hasil Penelitian Nilai-nilai Karakter pada Buku Pegangan Guru Kelas I Semester 1}

Buku teks Kurikulum 2013 pegangan guru tema "Diriku" ditulis oleh Lubna Assegaf, dkk dan terdiri atas 116 halaman. Fokus penanaman nilai karakter yang dikembangkan dalam setiap pembelajaran berbeda-beda. Berdasarkan hasil analisis, terdapat dua nilai dengan kemunculan terbanyak yaitu nilai kepercayaan diri, dan kedisiplinan. Kedua nilai karakter tersebut banyak dijadikan fokus penanaman nilai karakter pada pembelajaran dalam buku teks Kurikulum 2013 kelas I semester 1 tema diriku. Selain itu, urutan nilai karakter berdasarkan frekuensi terbanyak yaitu kepercayaan diri, kedisiplinan, kesantunan, religiositas, kepedulian, tanggung jawab, dan kejujuran. Hasil analisis juga menunjukkan terdapat nilai karakter lain yang muncul pada buku teks Kurikulum 2013 tema "Diriku", yaitu bekerja sama, teliti, rasa ingin tahu, peduli, patuh, kebersamaan, dan cermat.

Berdasarkan hasil analisis pada tema "Kegemaranku" diperoleh bahwa nilai ke percayaan diri, kesantunan, dan kedisiplinan muncul dengan frekuensi terbanyak dibandingkan nilai lainnya. Urutan nilai karakter dari yang terbanyak yaitu nilai kepercayaan diri, kesantunan, kedisiplinan, re ligiusitas, kepedulian, kejujuran, serta tanggung jawab. Pada tema "Kegemaranku" juga terlihat kemunculan nilai-nilai karakter pada bagian tujuan pembelajaran muncul secara tersurat. Hal ini berbeda jika dibandingkan dengan kemunculan nilai karakter pada tema "Diriku" yang muncul secara tersurat. Analisis juga dilakukan berdasarkan bagian-bagian buku yang ada. Hasil analisis menunjukkan bahwa nilai karakter paling banyak muncul pada bagian kegiatan pembelajaran. Hal ini menunjukkan bahwa dalam kegiatan pembelajaran akan banyak menanamkan nilai karakter baik pada diri peserta didik.

Tema tiga dalam buku teks Kurikulum 2013 kelas I semester 1 yaitu tema kegiatanku. Hasil penelitian menunjukkan bahwa ketujuh nilai karakter muncul pada buku teks Kurikulum 2013 pegangan guru tema kegiatanku. A kan tetapi, kemunculan masing-masing nilai karakter tetap didominasi oleh dua nilai tertinggi yaitu nilai kepercayaan diri dan nilai kesantunan. Hal ini dikarenakan bahwa kedua nilai karakter tersebut banyak dijadikan fokus penanaman nilai karakter serta banyak muncul pada bagian pembelajaran dalam buku teks Kurikulum 2013 tema “Kegiatanku”. Ber- 
dasarkan jumlah frekuensi terbanyak, dapat diurutkan nilai karakter dari yang terbanyak muncul yaitu nilai kepercayaan diri, kesantunan, kedisiplinan, religiusitas, tanggung jawab, kepedulian, serta kejujuran.

Tema terakhir yang dianalisis dalam penelitian ini adalah tema "Keluargaku". Hasil analisis dalam tema ini menunjukkan bahwa nilai kepercayaan diri muncul de ngan frekuensi yang sangat tinggi dan terpaut sangat jauh dengan nilai-nilai lainnya. Hasil ini menguatkan bukti bahwa nilai kepercayaan diri banyak dijadikan fokus pengembangan nilai karakter dalam setiap pembelajaran yang ada. Dalam tema ini juga terlihat penanaman nilai religiusitas yang muncul dengan sangat kuat dan baik pada subtema 4 pembelajaran 5 . Urutan nilai yang muncul berdasarkan frekuensi terbanyak yaitu nilai kepercayaan diri, kedisiplinan, kesantunan, religiusitas, kepedulian, tanggung jawab, dan kejujuran. Selain ketujuh nilai karakter tersebut, muncul juga nilai karakter lain pada buku teks ini, antara lain kasih sayang, cermat, teliti, bekerjasama, rasaingin tahu, tidak mudah menyerah, dan sikap mau menerima kekalahan.

Berdasarkan hasil penelitian beberapa tema, dapat disimpulkan bahwa nilai karakter kepercayaan diri yang paling banyak muncul pada buku teks Kurikulum 2013 pegangan guru. Keterangan lebih jelas dapat dilihat dalam Tabel 1 berikut.

Tabel 1 menunjukkan bahwa semua tema pada buku teks Kurikulum 2013 me ngembangkan semua nilai karakter. Nilai karakter tersebut sesuai dengan Peraturan Meneteri Pendidikan dan Kebudayaan Nomor 64 Tahun 2013 bahwasan terdapat 7 nilai karakter yang harus dikembangkan pada peserta didik kelas I semester 1 sekolah dasar. Nilai karakter tersebut yaitu nilai religiusitas (mewakili kompetensi religius), nilai kejujuran, kedisiplinan, tanggung ja- wab, kesantunan, kepedulian, dan kepercayaan diri (mewakili kompetensi sosial).

Tabel 1. Rekapitulasi Nilai Karakter pada Buku Pegangan G uru

\begin{tabular}{lccccc}
\hline \multirow{2}{*}{ Nilai } & \multicolumn{6}{c}{ Buku } & Pegangan Guru & Total \\
& I & II & III & IV & BG \\
\hline Religiusitas & 34 & 38 & 43 & 36 & 151 \\
Kejujuran & 6 & 12 & 9 & 6 & 33 \\
Kedisiplinan & 106 & 164 & 85 & 79 & 434 \\
Tanggung & 10 & 7 & 17 & 8 & 42 \\
Jawab & & & & & \\
Kesantunan & 47 & 165 & 103 & 71 & 386 \\
$\begin{array}{l}\text { Kepedulian } \\
\text { Kepercayaan }\end{array}$ & 11 & 20 & 15 & 9 & 55 \\
$\begin{array}{l}\text { Diri } \\
\quad \text { Jumlah }\end{array}$ & 394 & 383 & 332 & 277 & 1172 \\
\hline
\end{tabular}

Urutan nilai karakter berdasarkan frekuensi kemunculan yaitu nilai kepercayaan diri, kedisiplinan, kesantunan, religiusitas, kepedulian, tanggung jawab, dan kejujuran. Jika dilihat berdasarkan tema, nilai karakter paling banyak muncul pada tema 2 yaitu "Kegemaranku", tema 3 "Kegiatanku", tema 4 "Keluargaku", serta yang paling sedikit adalah tema "Diriku". Keterangan lebih jelas dapat dilihat pada Gambar 1.

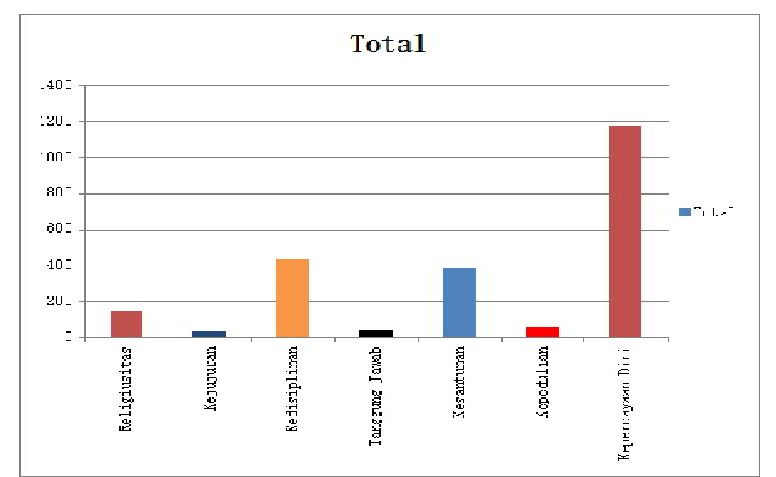

\section{Gambar 1. Rekapitulasi Nilai Karakter pada Buku Pegangan G uru}

Semua nilai karakter muncul dalam semua tema yang terdapat pada buku teks Kurikulum 2013 semester 1KelasI. Nilai kepercayaan diri, kedisiplinan, dan kesantunan muncul dengan jumlah paling banyak 
dikarenakan ketiga nilai karakter tersebut banyak digunakan dalam fokus penanaman nilai karakter dalam pembelajaran. Nilai karakter lain hanya muncul pada bagianbagian tertentu dalam buku teks KurikuIum 2013.

\section{Hasil Penelitian Nilai-nilai Karakter pada Buku Pegangan Siswa Kelas I Semester 1}

Seperti halnya paa buku teks Kurikulum 2013 pegangan guru, buku teks Kurikulum 2013 pegangan siswa juga terdiri atas 4 tema, yaitu tema "Diriku", "Kegemaranku", "Kegiatanku", dan tema "Diriku". Kegiatan pembelajaran yang terdapat pada buku pegangan siswa berupa kegiatan, cerita, gambar, petunjuk, serta soal-soal yang jelas, menarik dan mudah dipahami oleh peserta didik kelas I sekolah dasar. Langkah-langkah kegiatan pembelajaran yang terdapat pada buku pegangan siswa merupakan kegiatan yang telah direncanakan sebelumnya pada buku pegangan siswa. Oleh karena itu, nilai karakter yang akan dikembangkan merupakan nilai karakter yang telah dirancang pada buku pegangan siswa tema yang sama.

Berdasarkan hasil analisis buku teks Kurikulum 2013 pegangan siswa tema “Diriku" didapatkan data bahwa terdapat 3 nilai karakter yang muncul dengan frekuensi yang cukup banyak, 2 nilai karakter yang muncul dengan frekuensi sedikit, dan satu nilai karakter yang tidak muncul pada buku pegangan siswa. Tiga nilai karakter yang muncul dengan frekuensi cukup banyak yaitu nilai kepercayaan diri, kedisiplinan, serta nilai religiusitas. Ketiga nilai karakter tersebut muncul pada bagian buku seperti prapembelajaran, kegiatan pembelajaran, soal evaluasi, petunjuk kerja, serta kegiatan bersama orang tua. Dua nilai karakter yang muncul dengan frekuensi sedikit yaitu nilai kesantunan dan nilai tanggung jawab. $\mathrm{Ni}$ - lai karakter yang tidak muncul sama sekali pada buku pegangan siswa tema "Diriku" yaitu nilai kejujuran. Ketidakmunculan nilai kejujuran pada buku siswa tidak sejalan dengan kemunculan nilai karakter kejujuran pada buku pegangan guru tema yang sama.

Tema kedua pada buku teks Kurikulum 2013 yang dianalisis yaitu nilai "Kegemaranku". Berdasarkan hasil analisis, terdapat satu nilai karakter yang tidak memunculkan nilai karakter. Nilai karakter yang tidak muncul adalah nilai tanggung jawab. Keenam nilai karakter lainnya muncul dengan frekuensi yang bervariasi. Jika diurutkan dari yang terbesar, urutan nilai karakter yang muncul pada buku pegangan siswa yaitu nilai kepercayaan diri, kesantunan, kedisiplinan, religiusitas, kepedulian, kejujuran, dan tanggung jawab. Walupun memunculkan nilai karakter, namun nilai religiusitas, kepedulian, serta kejujuran muncul dengan frekuensi yang sangat sedikit. Nilai kejujuran sebagian besar muncul pada akhir kegiatan pembelajaran meIalui kegiatan bersyukur kepadaTuhan atas apa yang telah dimiliki. Nilai karakter kepercayaan diri, kesantunan, dan kedisiplinan muncul dengan frekuensi yang cukup besar dan muncul dalam setiap pembelajaran yang terdapat pada buku teks Kurikulum 2013 pegangan siswa.

Pengembangan nilai karakter juga muncul pada buku teks Kurikulum 2013 tema "Kegiatanku". Dalam tema "Kegiatanku", nilai kepercayaan diri, kesantunan, dan kedisiplinan muncul dengan frekuensi yang besar dibandingkan dengan nilai karakter lainnya. Ketiga nilai karakter tersebut muncul dengan frekuensi besar sejalan dengan fokus pengembangan nilai karakter yang terdapat pada buku teks Kurikulum 2013 pegangan guru. Selain itu, terdapat juga satu nilai karakter yang tidak muncul 
pada tema ini, yaitu nilai tanggung jawab. $\mathrm{H}$ asil analisis ini tidak sejalan dengan buku teks Kurikulum 2013 pegangan guru, karena pada buku pegangan guru semua nilai karakter muncul. Nilai-nilai karakter juga dianalisis berdasarkan bagian-bagian buku siswa. Berdasarkan bagian buku, pengembangan nilai karakter paling banyak muncul pada bagian aktivitas pembelajaran. Hal ini membuktikan bahwa nilai karakter muncul melalui kegiatan pembelajaran yang dilakukan oleh siswa.

Tema terakhir yang dianalisis pada penelitian ini adalah tema "Keluargaku". Pada buku pegangan siswa tema "Keluargaku", nilai karakter kepercayaan diri muncul dengan frekuensi sebanyak 67 kali. Nilai kepercayaan diri muncul dengan selisihyangcukup besar dibandingkan keenam nilai karakter lainnya. Berbeda dengan buku guru, dalam buku pegangan siswa nilai religiusitas muncul dengan frekuensi terbesar kedua setelah nilai kepercayaan diri. Pada buku pegangan siswa, khususnya subtema 4, pembelajaran 5 mengembangkan nilai religiositas dengan cukup menarik. Nilai religiositas dikembangkan melalui gambar, dan cerita mengenai perbedaan agama-agama yang dipercaya di Indonesia. Gambar tersebut antara lain gambar tempat ibadah masing-masing agama, perbedaan pakaian masing-masing agama, hari besar agama tertentu, serta bagaimana kita menghargai dan menghormati setiap pemeluk agama lain. Pengembangan nilai karakter religiusitas tersebut dirasa aukup jelas untuk peserta didik kelas 1 karena gambar terlihat sangat jelas, cerita juga jelas. Yang paling penting adalah penjelasan bagaimana caramenghargai perbedaan masing-masing pemeluk agama. Masing-masing siswa diberikan penjelasan agar tidak membeda-bedakan pertemanan berdasarkan agama tertentu.
Berdasarkan uraian masing-masing tema pada buku pegangan siswa kelas I semester 1 dapat dijelaskan bahwa nilai karakter kepercayaan diri, kesantunan, dan kedisiplinan muncul dengan frekuensi terbanyak dibandingkan dengan nilai karakter lainnya. Hasil ini sejalan dengan hasil analisis pada buku pegangan guru kelas I semester 1. Selain itu, terdapat perbedaan besar yang muncul pada pengembangan niIai-nilai karakter pada buku guru dan buku pegangan siswa seperti terlihat pada Tabel 2.

Tabel 2. Rekapitulasi Nilai Karakter pada Buku Pegangan Siswa

\begin{tabular}{lccccc}
\hline \multirow{2}{*}{ Nilai } & \multicolumn{6}{c}{ Buku Pegangan Siswa } & Total \\
& I & II & III & IV & BS \\
\hline Religiusitas & 25 & 9 & 10 & 24 & 68 \\
Kejujuran & - & 1 & 2 & - & 3 \\
Kedisiplinan & 29 & 42 & 20 & 16 & 107 \\
Tanggung Jawab & 5 & - & - & 1 & 6 \\
Kesantunan & 10 & 44 & 43 & 16 & 113 \\
Kepedulian & 9 & 5 & 6 & 11 & 31 \\
Kepercayaan Diri & 39 & 93 & 69 & 67 & 268 \\
$\quad$ Jumlah & 117 & 194 & 150 & 135 & 596 \\
\hline
\end{tabular}

Tabel 2 menunjukkan rekapitulasi nilai-nilai karakter yang dikembangkan pada buku pegangan siswa kelas I semester $1 \mathrm{se}$ kolah dasar. Berdasarkan Tabel 2 tersebut terlihat beberapa nilai karakter yang tidak muncul pada beberapa tema. Nilai karakter kejujuran tidak muncul pada tema "Diriku" dantema "Kegiatanku". Nilai karakter tanggung jawab tidak muncul pada buku teks Kurikulum 2013 tema "Kegemaranku" sertatema“"Kegiatanku". Ketidakmunculan nilai karakter tersebut tidak sejalan dengan kemunculan nilai karakter pada buku pegangan guru. Pada buku pegangan guru, semua nilai karakter muncul pada semua tema, walaupun dengan frekuensi yang sedikit. Keterangan lebih jelas dapat dilihat pada gambar berikut ini. 


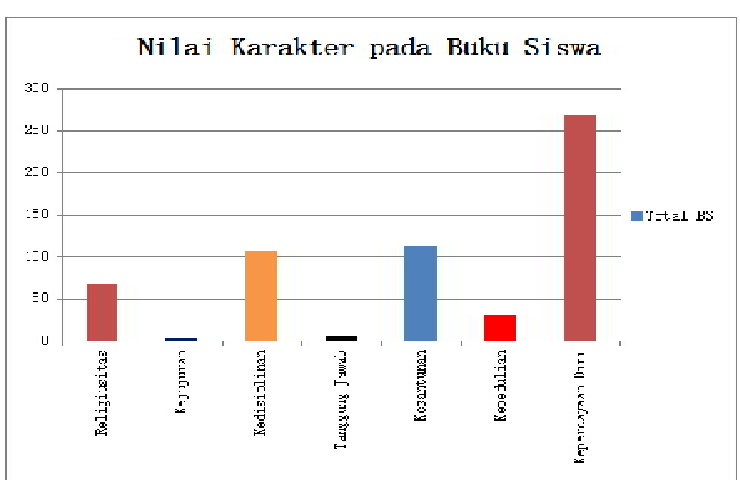

\section{G ambar 2. Rekapitulasi Nilai Karakter pada Buku Pegangan siswa}

Kemunculan nilai karakter juga dapat dilihat berdasarkan tema yang dianalisis. Pada buku teks Kurikulum 2013 pegangan siswa, terlihat urutan nilai karakter berdasarkan frekuensi. Urutan tersebut yaitu tema "Kegemaranku", tema "Kegiatanku", tema "Keluargaku", serta tema "Diriku". Hasil ini sejalan dengan buku teks Kurikulum 2013 pegangansiswa. Hal ini membuktikan bahwa buku teks Kurikulum 2013 pegangan guru dan siswa memunculkan nilai karakter yang tidak jauh berbeda.

\section{Kesesuaian Nilai-nilai Karakter pada Bu- ku Teks Kurikulum 2013 Pegangan Guru dan Pegangan Siswa}

Kesesuaian nilai-nilai karakter menganalisis nilai-nilai karakter yang terdapat pada buku pegangan guru dan pegangan siswa pada masing-masing pembelajaran. Proses analisis didasarkan pada pengembangan nilai karakter yang terdapat pada buku guru serta nilai karakter yang muncul pada buku siswa. Kedua pembelajaran dikatakan sesuai jika kedua buku teks Kurikulum 2013 mengembangkan nilai karakter yang sama. Sebaliknya keduanya dikatakan tidak sesuai jika nilai karakter yang muncul pada salah satu buku tidak sejalan dengan fokus penanaman nilai karakter, sertaterdapatperbedaan pengembangan nilai karakter pada buku pegangan guru dan pegangan siswa.
Nilai-nilai karakter yang muncul pada buku pegangan guru dan pegangan siswa tema "Diriku" sebagian besar sudah sesuai. Berdasarkan fokus pengembangan nilai karakter yang ada, baik buku pegangan guru dan pegangan siswa mengembangkan nilai karakter kepercayaan diri dan kedisiplinan. Hasil analisis juga menjelaskan bahwa ketidaksesuaian terjadi karena tiga fokus penanaman nilai karakter yang muncul pada buku pegangan guru hanya muncul satu nilai saja pada buku siswa.

Padatemaberikutnya yaitu tema “ $\mathrm{Ke}$ gemaranku", dari 24pembelajaran yang ada 17 nilai karakter menunjukkan kesesuaian, dan 7 nilai karakter belum menunjukkan kesesuaian. Sebagian pembelajaran yang tidak sesuai dikarenakan ketidakmunculan nilai karakter pada buku pegangan siswa. Beberapa pembelajaran yang tidak sesuai juga menunjukkan perbedaan pengembangan nilai karakter yang muncul pada buku pegangan guru dan buku pegangan siswa.

Hasil analisis pada tema "Kegiatanku" menunjukkan bahwa 13 pembelajaran tidak sesuai, dan 11 pembelajaran menunjukkan kesesuaian. Ketidaksesuaian pada buku teks Kurikulum 2013 dikarenakan pengembangan nilai karakter pada buku pegangan guru agak sedikit rancu. Nilai karakter yang terdapat pada fokus pengembangan nilai karakter tidak sesuai dengan nilai karakter yang terdapat dalam pembelajaran. Nilai karakter yang muncul pada kegiatan pembelajaran pada buku pegangan guru sering tidak muncul pada buku pegangan siswa pembelajaran yang sama.

Hasil yang tidak jauh berbeda juga terdapat pada buku teks Kurikulum 2013 tema "Diriku". Dari 24 pembelajaran yang dianalisis, hanya 7 pembelajaran yang menunjukkan kesesuaian, sedangkan 17 lainnya belum menunjukkan kesesuaian. Seba- 
gian besar ketidaksesuaian dikarenakan tidak munculnya nilai karakter kedisiplinan yang dijadikan fokus pengembangan nilai karakter pada salah satu buku teks. Nilai kedisiplinan muncul pada buku pegangan guru, namun tidak muncul pada buku pegangan siswa, begitu juga sebaliknya.

Simpulan yang dapat diambil berdasarkan hasil analisispadakeempat buku teks tersebut yaitu terdapat 2 tema yang memiliki kesesuaian yang cukup baik, sedangkan 2 tema lainnya banyak memunculkan ketidaksesuaian. Hasil ini menunjukkan bahwa buku teks Kurikulum 2013 masih perlu dilakukan revisi kembali khususnya pada pengembangan nilai-nilai karakter. $\mathrm{Hal}$ ini dikarenakan buku pegangan guru Kurikulum 2013 berisi rancangan pembelajaran yang akan dilaksanakan oleh guru dan siswa. Buku pegangan siswa merupakan buku teks yang berisi kegiatan pembelajaran yang mendukung aktivitas bersama guru di kelas. Jika terdapat perbedaan di antara kedua buku teks tersebut berarti terdapat nilai-nilai karakter yang tidak tersampaikan dengan baik kepada peserta didik.

\section{Pembahasan}

\section{Nilai-nilai Karakter pada Buku Pegangan G uru}

Hasil analisis buku teks Kurikulum 2013 pegangan guru kelas I semester 1 pada keempat tema menunjukkan bahwa semua nilai karakter muncul pada semua tema. Hal ini sejalan dengan Peraturan Menteri Pendidikan dan Kebudayaan Nomor 64 Tahun 2013 tentang Standar Isi Pendidikan Dasar dan Menengah. Dalam peraturan tersebut dijelaskan bahwa terdapat tujuh karakter yang harus dikembangkan. Oleh karena itu, agar tujuh karakter tersebut dapat berkembang dengan baik pada diri peserta didik, maka guru harus me- ngembangkan nilai-nilai karakter. Nilai-nilai tersebut antara lain nilai kepercayaan diri, kejujuran, kedisiplinan, tanggung jawab, kesantunan, kepedulian, dan kepercayaan diri.

Kemunculan nilai-nilai karakter pada buku teks Kurikulum 2013 juga sejalan de ngan sembilan karakter mulia yang dikembangkan oleh Megawangi (2004:95) dalam Indonesia H eritage Foundation. Sembilan karakter mulia tersebut yaitu cinta Tuhan dan segenap ciptaan-Nya; tanggung jawab, kedisiplinan, dan kemandirian; kejujuran atau amanah dan diplomasi; hormat dan santun; dermawan, suka menolong, dan gotong-royong atau kerja sama; percaya diri, kreatif, dan pekerja keras; kepemimpinan dan keadilan; baik dan rendah hati; serta toleransi, kedamaian dan kesatuan. Ketujuh nilai karakter yang harus ditanamkan pada peserta didik kelas I terdapat juga dalam sembilan karakter mulia yang dikembangkan oleh Megawangi tersebut.

Berdasarkan hasil anal isisterlihat bahwa pengembangan nilai-nilai karakter terfokus pada tiga nilai karakter saja. Ketiga nilai karakter tersebut yaitu nilai kepercayaan diri, kedisiplinan serta kesantunan. Nilai karakter lainnya muncul dengan frekuensi yang sedikit. Hasil analisis menjelaskan bahwa nilai karakter kepercayaan diri, kedisiplinan dan kesantunan muncul dengan frekuensi yang cukup tinggi. Selain itu, nilai karakter religiusitas, kepedulian, tanggung jawab dan kejujuran muncul dengan frekuensi yang sangat sedikit. Alasan utama keempat nilai karakter muncul dengan frekuensi yang rendah karena tidak dijadikannya fokus pengembangan nilai karakter pada masing-masing pembelajaran.

$\mathrm{Hal}$ tersebut tidak sejalan dengan nilai karakter yang perlu dikembangkan berdasarkan perkembangan emosi dari Santrock (2012:361). Perkembangan emosi 
peserta didik kelas rendah khususnya kelas I lebih menekankan pada emosi yang terdapat dalam diri sendiri. Kejujuran, tanggung jawab, dan kepedulian merupakan nilai karakter yang harus ditanamkan pada peserta didik. Hal ini sejalan dengan pendapat Santrock yang mengatakan bahwa pada masa sekolah dasar pemahaman emosi lebih mengarah pada kemampuan memahami emosi kompleks seperti rasa bangga dan malu. Namun, emosi-emosi ini kurang berkaitan dengan rekasi orang lain. Emosi tersebut akan lebih tergeneralisasi pada diri peserta didik jika disertadi dengan rasa tanggung jawab.

Berdasarkan penjelasan tersebut terlihat bahwa nilai tanggung jawab sangat penting ditanamkan kepada peserta didik kelas rendah. Nilai karakter tanggung jawab mendorong siswa untuk berani mengambil keputusan yang baik, melaksanakan pekerjaan atau perintah dengan bertanggung jawab, dan menyelesaikan tugas tepat waktu. Salah satu jalan keluar yang dapat diambil untuk mengatasi kekurangan pengembangan karakter tersebut yaitu meIalui pengembangan pembelajaran yang dilakukan sendiri oleh guru.

Proses pengembangan pembelajaran dapat dilakukan dengan strategi pembelajaran yang baik. Hal tersebut sejalan dengan pendapat Hidayatulloh (2010:39) bahwa strategi yang dapat digunakan dalam pembelajaran yaitu “keteladanan, penanaman kedisiplinan, pembiasaan, menciptakan suasana yang kondusif, serta integrasi dan internalisasi". Strategi pembelajaran dapat dilakukan secara bervariasi atau secara bersamaan dalam pembelajaran dan dalam peraturan sekolah. Oleh karena itu, walaupun buku teks kurang mengembangkan nilai karakter tertentu namun guru senantiasa mengembangkan nilai karakter yang diharapkan ada dalam diri siswa.
Hasil analisis juga menunjukkan bahwa terdapat beberapa nilai karakter yang muncul di luar tujuh nilai karakter yang dianalisis. Nilai karakter tersebut antara lain bekerja sama, teliti, cermat, sportif, rasa kasih sayang, rasa ingin tahu, dan toleransi. Beberapanilai karakter tersebutjugamuncul apda fokus pengembangan nilai karakter dan penilaian pembelajaran.

Nilai-nilai karakter yang tidak sesuai tersebut menunjukkan bahwa nilai karakter yang sebaiknya ditanamkan pada buku siswa bukan hanya tujuh, tetapi banyak. Nilai-nilai karakter tersebut juga muncul pada 18 nilai karakter yang dikembangkan oleh Kemdiknas pada tahun 2010. Pada 18 nilai karakter terdapat nilai rasa ingin tahu dan toleransi yang dapat dikembangkan. Hasil ini juga menunjukkan bahwa 18 nilai karakter masih kurang mencakup nilai karakter baik yang perlu dikembangkan pada diri peserta didik.

\section{Hasil Penelitian Nilai-nilai Karakter pada Buku Pegangan Siswa Kelas I Semester 1}

Berdasarkan analisis yang dilakukan pada buku pegangan siswa kelas I semester 1 terlihat bahwa semua nilai karakter muncul pada buku teks Kurikulum 2013 pegangan siswa kelas I semester 1 . Namun, jika dilihat lebih detail terdapat beberapa nilai karakter yang tidak muncul pada beberapa tema yang ada. Hasil analisis menunjukkan bahwa beberapa nilai karakter muncul dengan frekuensi yang sangat be sar, namun beberapa lagi muncul dengan nilai karakter yang sangat sedikit. Nilai karakter yang muncul dengan frekuensi besar antara lain nilai kepercayaan diri, kesantunan, kedisiplinan, dan religiusitas. Nilai karakter yang muncul dengan frekuensi sedikit yaitu nilai kepedulian, tanggung jawab serta nilai kejujuran. 
Nilai-nilai karakter yang muncul de ngan frekuensi yang sedikit tersebut tidak sejalan dengan perkembangan emosi peserta didik. Pendapat diperkuat dengan Humprey (2005:75), "Respect for self or others or property; honestly, self control or dicipline; responsibility or depen dability or accountability; integrity or fairness; perseverance or diligence; cooperation; compassion or empathy; kindness; forgiveness; patriotism or citizenship; tolerance or diversity; courtesy or politeness; generosity or charity; sportsmanship; humility." Kutipan tersebutmenjelaskan nilai karakter yangse baiknya muncul dan tidak sebaiknya muncul pada siswa. Berdasarkan penjelasan tersebut, terdapat nilai kejujuran, kedisiplinan, tanggung jawab, dan kesantunan yang sebaiknya berkembang pada diri siswa. Ke nyaatan tersebut tidak sejalan dengan hasil analisis pada buku teks Kurikulum 2013 kelas I semester 1 .

Nilai karakter kejujuran sangat penting ditanamkan kepada peserta didik. Hal ini sejalan dengan pendapat Yaumi (2014: 65) bahwa kejujuran bukan hanya diucapkan, bukan pula dijadikan simbol atau jargon, melainkan harus menjadi bagian yang tidak terpisahkan dengan perilaku, satunya kata dan perbuatan adalah intisari dari kejujuran. Pendapattersebut juga berlaku pada nilai karakter tanggung jawab dan kepedulian. Nilai karakter tersebut sangat penting ditanamkan kepada peserta didik agar siswa memiliki karakter jujur, bertanggung jawab, dan peduli. Karakter tersebut penting ditanamkan sejak kelas rendah agar dapat melekatpada pesertadidik sejak dini.

\section{Kesesuaian Nilai-nilai Karakter pada Buku Teks Kurikulum 2013 Pegangan Guru dan Pegangan Siswa}

Pengembangan nilai-nilai karakter pada buku teks Kurikulum 2013 pegangan guru dan pegangan siswa dapat dilihat berdasarkan jumlah frekuensi kemunculan nilai karakter. Berdasarkan hasil analisis terlihat perbedaan frekuensi kemunculan nilai karakter pada buku teks Kurikulum 2013 pegangan guru dan pegangan siswa. Berdasarkan hasil analisis terlihat jelas bahwa nilai karakter yang dikembangkan pada buku pegangan guru lebih banyak dibandingkan dengan nilai karakter yang dikembangkan pada buku pegangan siswa. Hal ini dikarenakan nilai karakter pada buku pegangan guru muncul pada semua bagian buku seperti kompetensi inti, kompetensi dasar, indikator, fokus pengembangan nilai karakter, tujuan pembelajaran, hingga penilaian. Pada buku siswa nilai karakter hanya terlihat pada kegiatan pembelajaran, kegiatan bersama orang tua, serta evaluasi.

Berdasarkan kesesuaian terlihat bahwa 2 tema menunjukkan kesesuaian yang baik dan 2 tema lainnya menunjukkan kesesuaian nilai karakter yang kurang baik. Kesesuaian yang baik terlihat pada buku tema "Diriku" dan "Kegemaranku". Kesesuaian yang kurang baik terlihat pada tema "Kegiatanku" dan "Keluargaku”. Padabuku tema "Diriku" dan "Kegemaranku" terlihat bahwa buku pegangan guru dan pegangan siswa menunjukkan kesesuaian nilai karakter yang baik.

Buku teks Kurikulum 2013 yang belummenunjukkankesesuaian yang baik perlu dilakukan revisi pada edisi berikutnya. Buku teks Kurikulum 2013 yang telah menunjukkan kesesuaian yang baik dapat dipertahankan dan dikembangkan kembali agar pengembangan nilai karakter pada edisi berikutnya lebih baik lagi. Pendapat tersebut sejalan dengan apa yang dikemukakan Bagdadi (2012:2):

"Textbook is considered the next important factor in the second/foreign language classroom after the teacher. Furthermore, due to students trust in their textbooks the influence of textbooks can be much stronger that words 
they hear from their parents of teachers."

Pendapat tersebut menunjukkan bahwa buku teks merupakan salah satu sumber belajar yang layak digunakan oleh peserta didik. Buku teks merupakan sesuatu yang penting dalam pembelajaran setelah guru. Buku teks dapat digunakan untuk mengembangkan nilai karakter melalui kegiatan yang ada dalam buku pegangan siswa.

\section{PEN UTUP}

Berdasarkan hasil penelitian dan pembahasan di atas, dapat diambil simpulan sebagai berikut. Pertama, buku teks Kurikulum 2013 pegangan guru secara keseluruhan memuat tujuh nilai karakter sesuai dengan Peraturan Menteri Pendidikan dan Kebudayaan No. 64 Tahun 2013 tentang Standar Isi Pendidikan Dasar dan Menengah. Nilai-nilai karakter tersebut adalah religiusitas, kejujuran, kedisiplinan, tanggung jawab, kesantunan, kepedulian dan kepercayaan diri. Frekuensi kemunculan nilai-nilai karakter tersebut tergantung dari fokus pengembangan karakter dan tema yang disajikan. Kedua, nilai karakter pada buku pegangan siswa secara keseluruhan telah memuat nilai karakter sesuai dengan Peraturan Menteri Pendidikan dan Kebudayaan N o. 64 Tahun 2013 tentang Standar Isi Pendidikan Dasar dan Menengah. Namun, jika dilihat berdasarkan tema, terdapat beberapa nilai karakter yang mengembangkan nilai karakter. Nilai karakter kejujuran tidak muncul pada buku teks KurikuIum 2013 tema "Diriku" dan "Keluargaku". Nilai karakter tanggung jawab tidak muncul pada buku teks Kurikulum 2013 tema "Kegemaranku" dan "Kegiatanku". Ketiga, kesesuaian nilai karakter juga menunjukkan hasilyang beragam. Tema "Diriku" dan "Kegemaranku" menunjukkan kesesuaian yang baik antara buku pegangan guru dan buku pegangan siswa. Hal ini berbeda de ngan pada tema "Kegiatanku" dan "Keluargaku" yang belum memperlihatkan kesesuaian yang baik antara buku pegangan guru dan buku pegangan siswa.

\section{UCAPAN TERIMA KASIH}

Dalam kesempatan ini penulis mengucapkan terima kasih yang setulus-tulusnya kepada para dosen di Prodi Dikdas Program Pascasarjana yang telah memberikan bekal ilmu yang sangat berharga. Penulis juga mengucapkan terima kasih kepada Ketua Dewan Redaksi Jurnal Pendidikan Karakter beserta anggotanya yang telah menerima, merevieu, dan memuat tulisan ini pada edisi ini. Semoga tulisan ini bermanfaat bagi para pembaca.

\section{DAFTAR PUSTAKA}

Bagdadi, M. 2012. "A Comparison of Gender Representation in English (EFL) and Arabic (AFL) Textbooks in Iran: A Critical Discourse Analysis". The Humanities and Social Sciences Collection, Vol. 8, No. 3, pp. 1-13.

Bohlin, K. E. 2005. Teaching Character Education Through Literature, A wakening the $M$ oral Imagination in Secondary Classrooms. London: Routledge Falmer.

Costanzo, R.D. 2009. “The Function and Use of The Textbook in an Undergraduate N ursing Program". TheH umanities and Social Sciences Collection, Vol. 13, No. 5, pp. 1-10.

El-Saleh I. 2011. “Teachers Concern Regarding the Adoption of the New Mathematics Textbooks". TheH umanities and Social Sciences Collection, Vol. 3, No. 5, pp. 1-9.

Hidayatulloh, F. 2010. Pendidikan Karater, Membangun Peradaban Bangsa. Sura- 
karta: Yuma Pustaka.

Humphrey, M. 2005. Living the H ero's Q uest: Character Building Through Action Re search. New York: Libraries Unlimited.

Kemdikbud. 2014. M ateri Pelatihan Guru Implementasi Kurikulum 2013 SD kelas 1. Kementrian Pendidikan dan Kebudayaan.

Krippendorf, K. 2013. Content A nalysis: A n Introduction to Its M ethodology. Thousand Oaks: SA GE.

Megawangi, R. 2004. Pendidikan Karakter: Solusi yang Tepat untuk Membangun Bangsa. Bogor: Indonesia Heritage Foundation.

Muryaningsih, S. \& Mustadi, A. 2015. "Pe ngembangan RPP Tematik-Integratif untuk Meningkatkan Karakter Kerja Keras di Kelas 1 SD N 2 Sokaraja Te ngah". Jurnal Prima Edukasia, Vol. 3, No. 2, pp. 190 - 201.

Nucci, L. \& Narvaez, D. 2008. Handbook of $M$ oral and Character Education. New York: Routledge.

Peraturan Menteri Pendidikan dan Kebudayaan No. 160 Tahun 2014 tentang Pemberlakuan Kurikulum Tahun 2006 dan Kurikulum 2013.
Peraturan Menteri Pendidikan dan Kebudayaan No. 64 Tahun 2013 tentang Standar Isi Pendidikan Dasar dan Menengah.

Peraturan Menteri Pendidikan dan Kebudayaan Nomor 57 Tahun 2014 tentang Kurikulum 2013 Sekolah Dasar/ Madrasah Ibtidaiyah.

Qodriyah, S. \& Wangid, M. 2015. “Pengembangan SSP Tematik Integratif untuk Membangun Karakter Kejujuran dan Kepedulian Siswa SD Kelas II". Jurnal Prima Edukasia, Vol. 3, No. 2, hIm. 177 - 189.

Santrock, J. W. 2012. Perkembangan M asa H idup Edisi Ketigabelas. (Terjemahan Benedictine Widyasinta). New York: McGraw-Hill Companies, Inc.

Sasmito, L. \& Mustadi, A. 2015. “Pengembangan Lembar Kerja Peserta Didik Tematik Integratif Berbasis Pendidikan Karakter pada Peserta Didik Sekolah Dasar". Jurnal Pendidikan Karakter, Vol. V, No. 1, hlm. 67-79.

Yaumi, M. 2014. Pendidikan Karakter; Landasan Pilar \& Implementasi. Jakarta: Prenamedia Group. 